\title{
Declaration of Principles on the Grand Ethiopian Renaissance Dam: Some Issues of Concern
}

Dereje Zeleke Mekonnen *

\begin{abstract}
The Nile Basin has long been noted as a potential flashpoint for resource conflict on account of the prevalence of inequitable water utilization and acrimonious inter-riparian relations. The basin's proneness to conflict has been exacerbated by the absence of an inclusive legal and institutional framework governing the utilization and management of its meager water resources. Unilateralism and incompatible riparian claims negating the fundamentals of international water law still continue to be the defining features of the basin. Launched in such a setting, the Grand Ethiopian Renaissance Dam (GERD) constitutes a significant counter-hegemonic measure capable of inducing a positive transformation in the basin's inequitable status quo. A lasting solution which would ensure the equitable and sustainable utilization of the Nile waters for the benefit of all is, however, still elusive as the signing of the Declaration of Principles (DoP) poses challenges which might arguably neutralize the transformative impact of the GERD and entail institutionalization of the status quo.
\end{abstract}

\section{Key terms}

GERD · Declaration of Principles · International Water Law · Equitable Utilization · Nile Basin

DOI http://dx.doi.org/10.4314/mlr.v11i2.1

Received: 8 August 2017 Accepted: 26 December 2017

This article is licensed under a Creative Commons AttributionNonCommercial-NoDerivs (CC BY-NC-ND)

\section{Introduction}

Cooperative development and utilization of transboundary watercourses carries enormous potential economic benefits for riparian states. In the absence of

\footnotetext{
* Dereje Zeleke Mekonnen, PhD, Associate Professor, School of Law, Addis Ababa University; Email: dereje.zeleke@aau.edu.et
} 
cooperation where competition and unilateral actions often constitute the modus operandi, trans-boundary watercourses pose huge risk of being cause for conflict. The enormity of the potential benefits and the seriousness of the risk are, arguably, more evident in the Nile basin than in other major international basins.

According to Sadoff and Grey, cooperation offers riparian states a wide spectrum of benefits of an economic, environmental and political nature. ${ }^{1}$ In the Nile basin, the economic value of cooperation involving limited infrastructure development in the Blue Nile sub-basin has been estimated to be between USD 1.15 billion and 1.97 billion. $^{2}$ Utilization of Nile water for irrigation and hydroelectric power generation has been estimated to generate an annual gross economic benefit to the tune of USD 11 billion. $^{3}$

Tapping the enormous potential benefits of the Nile waters through cooperative development and equitable utilization requires overcoming the many challenges which not only make realization of these benefits extremely difficult but also aggravate the basin's proneness to conflict. The difficult hydrologic environment of the basin, ${ }^{4}$ especially the relatively small discharge, ${ }^{5}$ the hegemonic hydro-political configuration prevalent in the basin, ${ }^{6}$ the

${ }^{1}$ C. Sadoff \& D. Grey (2002), "Beyond the River: The Benefits of Cooperation on International Rivers”, 4 Water Policy, pp. 389-403. The authors point out four major benefits of cooperation: benefits to the river, benefits from the river, reducing costs because of the river, and benefits beyond the river.

${ }^{2}$ D. Whittington, X. Wu \& C. Sadoff (2005), "Water Resources Management in the Nile Basin: The Economic Value of Cooperation”, 7Water Policy, p. 249.

${ }^{3}$ Ibid.

4 D. Grey \& C. Sadoff (2007), "Sink or Swim? Water Security for Growth and Development", 9 Water Policy, p. 548. The hydrologic environment of a basin which refers to "the absolute level of water resource availability, its inter- and intra-annual variability and its spatial distribution" is said to be difficult "where rainfall is markedly seasonal - a short season of torrential rain followed by a long dry season [which] requires the storage of water; or where there is high inter-annual climate variability, where extremes of flood and drought create unpredictable risks to individuals and communities and to nations and regions and require over-year water storage.” Ibid., p. 549.

${ }^{5}$ N. Kliot (1994), Water Resources and Conflict in the Middle East, (London, Rutledge), p. 13. The 84 billion cubic metres annual flow of the Nile is the lowest discharge of comparable large rivers. R. Collins (2002), The Nile (New Haven \& London: Yale University Press), p. 11, gives a figurative description of the small flow of the Nile which constitutes only "a mere cup ( 2 per cent) of the Amazon, perhaps a glass (15 per cent) of the Mississippi, or at best a pitcher (20 per cent) of the Mekong."

${ }^{6}$ M. Woodhouse \& M. Zeitoun (2008), "Hydro-hegemony and International Water Law: Grappling with the Gaps of Power and Law", 10 Water Policy Supplement 2, p. 113. The authors describe Egypt's hegemonic position in the Nile basin as a malign form of hydrohegemony maintained in utter disregard of the principles of international water law. 
comparatively poor and rancorous inter-riparian relationship, ${ }^{7}$ and the absence of an inclusive legal framework are some of the major hurdles ${ }^{8}$ which have forced many observers to make ominous predictions of conflict over the Nile waters. ${ }^{9}$

Although the basin embarked on a new era of unprecedented cooperation and optimism following the launching, in February 1999, of the Nile Basin Initiative (NBI), hard-won rapprochement began to give way to acrimonious dispute following rejection of the Cooperative Framework Agreement (CFA) by Egypt and Sudan. At the heart of the problem lies the fate, vis-à-vis the CFA, of "existing treaties", i.e., the 1929 and 1959 treaties on the basis of which Egypt and Sudan claim historical rights over the entire flow of the Nile. In common legal parlance, the problem pertains to disagreement over a proposed amendment to Article 14(b) of the CFA on water security. In reality though, it signifies an about-face on the shared vision of the $\mathrm{NBI}^{10}$ which affirms the determination of Egypt and Sudan to deny upstream riparian countries of their right to any consumptive utilization of the Nile waters.

This article argues that the launching of the GERD at a critical moment in the history of Nile riparian cooperation offers a unique opportunity for change as it represents a potent counter-hegemonic measure the recalcitrant downstream riparian states cannot afford to be indifferent about. The first real opportunity for change towards cooperative development and equitable utilization, it will be argued, is however threatened by unfolding developments which might neutralize the impact of the GERD and institutionalize the untenable status quo in a new legal framework involving erosion of the fundamental principles of international water law.

\footnotetext{
${ }^{7}$ For a discussion of the poor inter-riparian relationship and the reasons thereof, see Dereje Z. Mekonnen (2013), “The Quest for Equitable Resolution of the Nile Waters Dispute: Wandering in the Wilderness?” International Journal of Ethiopian Studies VII (1 \& 2), pp. 81-87.

${ }^{8}$ For a detailed discussion of the various challenges, see Dereje Z. Mekonnen (2011), "Between the Scylla of Water Security and Charybdis of Benefit Sharing: The Nile Basin Cooperative Framework Agreement - Failed or Just Teetering on the Brink?” Goettingen Journal of International Law 3(1), pp. 349-355.

9 J. Kerisel (2001), The Nile and its Masters: Past, Present, Future (Rotterdam: A.A. Balkema Publishers), p. 164; Kliot, supra note 5, p. 18.

${ }^{10}$ The NBI was launched under the shared vision "to achieve sustainable socio-economic development through the equitable utilization of, and benefits from, the common Nile Basin water resources." Claiming historical right over the entire flow and thus denying other riparian states of any share thereof obviously negates the very substance of the shared vision.
} 


\section{The Untenable Status Quo}

The status quo in the Nile basin is the product of lopsided colonial treaties which, in total disregard to the rights of other riparian states, were designed to serve British colonial interests downstream in Egypt and Sudan. As a result, the basin exhibits a distinctively inequitable pattern of water utilization not seen in any other international basin. Although the Nile is shared by 11 riparian states with burgeoning populations and economies highly dependent on agriculture, the status quo vests Egypt and Sudan -downstream riparian states with little or negative contribution ${ }^{11}$ with exclusive right over the entire flow. It is this extremely inequitable state of affairs which Egypt and Sudan claim as their nonnegotiable historical right. This claim, which has recently been rebranded as 'water security', has its roots in the 1929 Agreement which was further reinforced by the 1959 Agreement. Both agreements, however, have no legal force binding upon the upstream riparian states and hence, the inequitable status quo they allegedly undergird has no basis in international law.

\subsection{The 1929 Agreement}

Concluded through the exchange of notes between Egypt and the United Kingdom, the 1929 agreement ${ }^{12}$ constitutes the mainstay of the status quo in the Nile basin. The agreement allocated the then utilizable flow of the Nile to Egypt and Sudan in the ratio of 48 and 4 billion cubic metres as their respective 'acquired rights' ${ }^{13}$ The agreement was made in the aftermath of a political tension between the governments of Britain and Egypt which reached its peak in 1924 when Egyptian nationalists demanding unity of Sudan with Egypt killed the British Governor-General of Sudan. ${ }^{14}$ Britain responded with a threat to reduce the flow of the Nile by an unlimited increase in Sudanese irrigation. ${ }^{15}$ When the matter was finally settled in 1929, Egypt recognized Sudan's right to

${ }^{11}$ Kliot, supra note 5, pp. 23, 25 and 39, pointing out the fact that Egypt and Sudan are points of great water loss in the Nile basin. The Sudd swamp in the South Sudan is the point of the biggest loss where between 12 and 30 billion cubic metres of water is lost annually. In Egypt, between 12 and 15 billion cubic metres of water is lost annually due to evaporation from Lake Nasser in addition to the 0.6 to 2 billion cubic metres lost annually due to seepage.

${ }^{12}$ Agreement on the Use of the Waters of the River Nile for Irrigation Purposes, concluded on the $7^{\text {th }}$ of May 1929, in Cairo, available at http://ocid.nacse.org/tfdd/tfdddocs/92ENG.pdf (last visited 20 July 2017).

13 Tesfaye Tafesse (2001), The Nile Question: Hydropolitics, Legal Wrangling, Modus Vivendi and Perspectives (Piscataway, NJ: Transaction Publishers), pp. 74-75.

14 J. Dellapenna (1997), “The Nile as a Legal and Political Structure”, in E. Brans et al (eds.), The Scarcity of Water: Emerging Legal and Policy Responses (Kluwer Law International), p. 125.

${ }^{15}$ Ibid. 
utilize an increased quantity of the Nile waters while Britain, in addition to recognizing Egypt's natural and historical rights in the Nile waters, agreed to make safeguarding of the rights a fundamental principle of its policy. ${ }^{16}$

The agreement which was concluded eight decades ago between Egypt and Britain is claimed to have a continued binding force on the former British colonies of Kenya, Uganda and Tanzania as successor riparian states. For the obvious fact that Ethiopia was never a British colony, any discussion on whether or not the 1929 agreement has a continued binding force is of no relevance. The claim though has no legal basis even with regards to the former British colonies as it is rooted in the theory of universal succession which entails the compulsory transfer of all the rights and obligations of the predecessor state to its successors. ${ }^{17}$ International law applies, with regards to succession to treaties, the clean slate (tabula rasa) theory which relieves the successor states of any duty to be bound by the obligations of the predecessor state. ${ }^{18}$ Contrary to the unfounded claim of wholesale transmission of treaty rights and obligations, succession in respect of the 1929 agreement has entailed "discontinuity of all rights and obligations completely and automatically". ${ }^{19}$

The independent successor states could, of course, extend the binding effect of the agreement either through the conclusion of devolution agreements or by declaring to be bound by it. ${ }^{20}$ What they did upon independence though is the exact opposite: Tanganyika (now Tanzania) declared the 1929 agreement not binding upon it in identical notes addressed to the governments of Britain, Egypt and Sudan on 4 July 1964; Uganda and Kenya followed Tanganyika in rejecting the agreement on the same grounds. ${ }^{21}$ There is, therefore, no legal basis to ensure the continued binding force of the 1929 agreement even on the former British colonies of Kenya, Tanzania and Uganda. ${ }^{22}$

${ }^{16}$ Dereje Z. Mekonnen (2010), “The Nile Basin Cooperative Framework Agreement Negotiations and the Adoption of a Water Security Paradigm: Flight into Obscurity or a Logical Cul-de-sac?” European Journal of International Law 21(2), p. 432.

${ }^{17}$ Id., pp. 432-433.

${ }^{18}$ Ibid.

${ }^{19}$ Yilma Mekonnen (1986), "State Succession in Africa: Selected Problems”, 200 Recueil de Cours international (V), pp. 107-108.

${ }^{20}$ Dereje, supra note 16, p. 434.

${ }^{21}$ S. McCaffrey (2001), The Law of International Watercourses: Non-Navigational Uses (Oxford: Oxford University Press), pp. 245-246.

${ }^{22}$ P. Howell (1994), “East Africa's Water Requirements: the Equatorial Nile Project and the Nile Waters Agreement of 1929: A Brief Historical Review”, in P. Howell \& J. Allan (eds.), The Nile: Sharing a Scarce Resource: An Historical and Technical Review of Water Management and of Economical and Legal Issues (Cambridge University Press), p. 86. The claim is not only bereft of any legal basis in international law but is also factually unfounded. Through the East African Nile Waters Coordinating Committee established in 


\subsection{The 1959 Agreement}

The Agreement for the Full Utilization of the Nile Waters ${ }^{23}$ signed by Egypt and Sudan on 8 November 1959 is a patently anomalous deal which, though a purely bilateral treaty entered into between two downstream riparian states making very little contribution to the flow, "seeks to apportion the entire flow of the Nile to Egypt and Sudan, excluding the interests of any other riparian, notably Ethiopia”. ${ }^{4}$

The agreement reaffirmed the 'acquired rights' of Egypt and Sudan to 48 and 4 billion cubic meters respectively. It also allocated the 22 billion cubic metres of Nile water to be made available through the construction of the Sudd el Ali (Aswan) and Roseires dams to Egypt and Sudan which received 7.5 and 14.5 billion cubic metres respectively realizing, thereby, the full control and utilization of the Nile waters by the two parties. ${ }^{25}$ The agreement has apportioned the entire flow of the Nile to Egypt and Sudan, further raising their respective share to 55.5 and 18.5 billion cubic metres and leaving, thus, literally no water for the nine upstream riparian states.

Unlike the 1929 Agreement, the 1959 Agreement is the first agreement concluded by independent riparian states. In terms of substance and objective, however, it is not different from the 1929 agreement as it purportedly created a complete monopoly over the waters of the Nile. Despite the baseless claim of the parties, the complete monopoly created by the agreement has no legal basis whatsoever. As a bilateral treaty signed by Egypt and Sudan, whatever rights and obligations it created bind only the parties. ${ }^{26}$ For the upstream riparian states which are third parties, the agreement is of no legal significance as it neither confers any right nor imposes any obligation on them. ${ }^{27}$

1955 to represent the interests of Kenya, Tanzania and Uganda with a view to determining a common policy, the East African governments had declared their inherent and indisputable right to a share of the Nile waters. Likewise, the Government of Britain of the day had, in a 22 November 1955 Note to the Egyptian and Sudanese Governments, reserved the right of the East African territories to negotiate an agreed share of the Nile waters.

${ }^{23}$ Agreement between the Republic of the Sudan and the United Arab Republic for the Full Utilization of the Nile Waters, Cairo (8November 1959) available at:

http://ocid.nacse.org/qml/research/tfdd/toTFDDdocs/110ENG.pdf (last visited 20 July 2017)

24 J. Brunnee \& S. Toope (2002), “The Changing Nile Basin Regime: Does Law Matter?’, 43 Harvard Int'l Law Journal, pp. 125-126.

${ }^{25}$ Dereje, supra note 16, p. 435.

${ }^{26}$ Articles 34 and 35, Vienna Convention on the Law of Treaties 1969, 1155 UNTS 331.

${ }^{27}$ Id., Articles 34, 35 and 36. 


\section{International Water Law: The Fundamentals}

The international legal regime governing the utilization and management of shared international watercourses is anchored in the 1997 UN Convention on the Law of the Non-Navigational Uses of International Watercourses. ${ }^{28}$ The Convention which is "generally regarded as reflecting the fundamental rules of customary international law applicable in the field," 29 sets forth general principles $^{30}$ that govern the conduct of riparian states sharing international watercourses. The most fundamental principles which define the rights and obligations of riparian states are the principle of equitable and reasonable utilization and the obligation not to cause significant harm.

\subsection{Equitable and Reasonable Utilization}

Rooted in the principle of sovereignty, the principle of equitable and reasonable utilization affirms the right of riparian states to utilize, in their respective territories, an international watercourse in an equitable and reasonable manner. ${ }^{31}$ The primary function of the principle is to establish "entitlement to the use of volumes of water or entitlement to undertake certain activities on an international watercourse."32 It is a principle "chiefly [...] governing apportionment, or allocation, of water between states sharing an international watercourse". ${ }^{33}$ In terms of normative status, there is "no rule of international law concerning the use of international watercourses more fundamental than that of equitable and reasonable utilization." ${ }^{34}$

Determination of what is equitable and reasonable in a given case is made by taking into account all relevant factors and circumstances an indicative list of which is provided under Article 6 of the UN Watercourses Convention. ${ }^{35}$ The

${ }^{28}$ UN Convention on the Law of the Non-Navigational Uses of International Watercourses 1997, (1997) 36 ILM 700.

${ }^{29}$ A. Grzybowski, S. McCaffrey \& R. Paisley (2010), "Beyond International Water Law: Successfully Negotiating Mutual Gains Agreements for International Watercourses”, 22 Global Business \& Development Law Journal, p. 141.

30 The general principles provided for in part two of the Convention are: equitable and reasonable utilization and participation, factors relevant to equitable and reasonable utilization, obligation not to cause significant harm, general obligation to cooperate, regular exchange of data and information, and relationship between different kinds of uses.

${ }^{31}$ UN Watercourses Convention, supra note 28, Article 5.

32 X. Fuentes (1998), "Sustainable Development and the Equitable Utilization of International Watercourses”, 69 British Yearbook of International Law, p. 137.

${ }^{33}$ S. McCaffrey, supra note 21, p. 325.

${ }^{34}$ Grzybowski, McCaffrey \& Paisley, supra note 29, p. 141.

35 The non-exhaustive list of factors relevant to the determination of equitable and reasonable utilization listed under Article 6 are: (a) geographic, hydrographic, 
fact that the Convention mentions "existing and potential uses of the watercourse" among the factors to be taken into account in the determination of equitable and reasonable utilization signifies the illegitimacy of the 'historical rights' claim Egypt and Sudan make to the entire flow of the Nile.

\subsection{Obligation Not to Cause Significant Harm}

In the context of shared international watercourses where all riparian states have the right to equitable and reasonable utilization in their respective territories, there is a higher likelihood for violation of the rights of some riparian states by others. The obligation not to cause significant harm is another fundamental principle of international water law which circumscribes the right to equitable and reasonable utilization by obliging watercourse states, while utilizing an international watercourse in their territories, "to take all appropriate measures to prevent the causing of significant harm to other watercourse states."36

In view of the significant impact the obligation has in determining the legitimacy and propriety of a given utilization, understanding the true purport of the prohibition is crucial. Accordingly, what the obligation pertains to is "harm as a legal injury" and not to "factual harm". Hence, "what is prohibited is conduct by which one state exceeds its equitable share, or deprives another state of its equitable share of the uses and benefits of the watercourse." 37

Application of the obligation thus presupposes a prior determination of the specific rights of riparian states where any utilization in excess of one's equitable share or depriving another state of the same would be a violation of international law. In the absence of a legal framework determining the specific rights of riparian states, there is no room for application of the obligation. In the context of the Nile basin though, it is Egypt and Sudan which, by apportioning the entire flow to themselves and foreclosing future uses by upstream riparian states, ${ }^{38}$ stand in flagrant violation of the obligation. Being downstream riparian

hydrological, climatic, ecological and other factors of a natural character; (b) social \& economic needs of watercourse states; (c) population dependent on the watercourse; (d) effects of use in one watercourse state on other watercourse states; (e) existing and potential uses; (f) conservation, protection, development and economy of use and the costs of measures taken to that effect; and (g) the availability of alternatives, of comparable value, to a particular planned or existing use.

${ }^{36}$ UN Watercourses Convention, supra note 28, Article 7(1).

37 S. McCaffrey (1986), "Second Report on the Law of the Non-Navigational Uses of International Watercourses”, 2 Yearbook of International Law Commission 2(1), p. 133.

${ }^{38}$ Downstream riparian states in general and Egypt and Sudan in particular tend to perceive the obligation as proscribing upstream riparian states from making use of the shared watercourse even when such legitimate exercise of a right causes only factual harm. Contrary to this erroneous understanding, the obligation proscribes downstream 
states, there is little they can do to foreclose utilization by upstream riparian states. It is evident, therefore, that the untenable status quo and the unfounded claim to veritable ownership of the entire flow of the Nile would inevitably crumble if and when significant hydraulic projects like the GERD become reality.

\section{The GERD: A Harbinger of Change?}

The quest for equity and fairness in the utilization of the Nile waters spans a period of over five decades with a series of unsuccessful cooperative initiatives. ${ }^{39}$ In spite of the immense hope and optimism which surrounded the launching of such initiatives, change in the inequitable status quo has proven to be more of a chimera than an attainable objective. The history of basin-wide cooperative initiatives from Undugu to the NBI is a history of failure in terms of bringing about change in the iniquitous status quo.

Launched in 1983 upon the proposal of Egypt, Undugu was the first basinwide cooperation initiative which served as a platform for the discussion of matters pertaining to the Nile waters within a broad array of issues including agriculture, resource development, promotion of economic, technical and scientific cooperation among the riparian states. ${ }^{40}$ The five founding members of Undugu - Egypt, Sudan, Uganda, the DRC and the Central African Republic were joined by Burundi, Rwanda and Tanzania whereas Ethiopia and Kenya participated as observers. ${ }^{41}$

Compared to the prevalent pattern of riparian cooperation the hallmarks of which were bilateralism and exclusive focus on technical issues, Undugu could be regarded as a major step forward as it involved almost all the riparian countries and purported to address a wide spectrum of issues. It also succeeded in making modest contributions to the development of the basin through factfinding activities carried out with the support of the UNDP to help the formulation of a comprehensive economic plan including water resource development. ${ }^{42}$

In terms of bringing about change in the basin's inequitable status quo, or even the hope for such a change, Undugu was a complete failure which arguably undermined the incipient mutual trust amongst riparian states. The primary reason for the failure and subsequent deterioration of inter-riparian relations was

utilizations which foreclose or curtail future uses upstream (Grzybowski, McCaffrey and Paisley, supra note 29, p. 142).

${ }^{39}$ Dereje, supra note 7, pp. 81-87.

${ }^{40}$ Ibid., p. 85.

${ }^{41}$ Ibid.

${ }^{42}$ Ibid. 
lack of genuine commitment on the part of Egypt which used the initiative as a tool for hegemonic influence. ${ }^{43}$ In a manner typical of an oppressive hydrohegemon, ${ }^{44}$ Egypt insisted that the top agenda of Undugu should be hydropower generation through joint hydroelectric projects connecting the national electricity grids of the riparian countries proceeding, at the same time, with its own giant irrigation and land reclamation projects. ${ }^{45}$ Abused by its progenitor and perceived, arguably appropriately, as an Egyptian ploy to contain the upstream riparian states, ${ }^{46}$ Undugu evanesced leaving the riparian states in a state of deeper mistrust and suspicion.

The history of the Technical Cooperation Committee for the Promotion of the Development and Environmental Protection of the Nile (Tecconile), another basin-wide cooperative scheme initiated by Egypt, is not different from its predecessor in terms of bringing about change in the status quo. Although it was considered to be a new arrangement which had managed to stave off the political dominance Egypt has had on Undugu, ${ }^{47}$ Tecconile remained strongly technical in its focus thereby constraining upstream riparian countries like Ethiopia from becoming full members. ${ }^{48}$ One remarkable achievement of the Tecconile is, of course, the Nile River Action Plan which was formally approved by the Council of Ministers of Water Affairs in 1995 in Arusha, Tanzania. ${ }^{49}$ In much the same way as that of Undugu, the significance of Tecconile was neutralized as an important component of the Action Plan on Regional Cooperation which envisaged the establishment of a basin-wide legal and institutional framework failed to materialize. ${ }^{50}$

Tecconile was, one can argue, redeemed from being a total failure by Ethiopia's insistence on the inclusion of the determination of equitable entitlement of riparian states to the Nile waters as a priority issue in the Action Plan. Unanimously approved as a priority project and incorporated into the Action Plan as such, the Nile Basin Cooperative Framework provided the basis

${ }^{43}$ Ibid.

${ }^{44}$ M. Woodhouse \& M. Zeitoun M (2008), "Hydro-hegemony and International Water Law: Grappling with the Gaps of Power and Law”, 10 Water Policy, Supplement 2, p. 113.

${ }^{45}$ Ibid.

${ }^{46}$ A. Soffer (1999), Rivers of Fire: The Conflict over Water in the Middle East (Lanham, MD: Rowman \& Littlefield Publishers), p. 62. The initiative was launched with the objective of maintaining the status quo by preventing the utilization of the Nile waters upstream and Undugu was intended to be a tool for the supervision and control of Nile water utilization upstream.

${ }^{47}$ Brunee \& Toope, supra note 24, p. 133.

${ }^{48}$ Dereje, supra note 16, p. 427.

${ }^{49}$ Ibid.

${ }^{50}$ Brunnee \& Toope, supra note 24, p. 135. 
for the next basin-wide cooperative initiative launched in 1999 in the form of the NBI. ${ }^{51}$

The launching of the NBI was a milestone which evoked immense hope and optimism unprecedented in the basin's history. What made the NBI radically different from previous initiatives was the determination, from the outset, of the basin states to make the long eschewed issue of equitable utilization of the Nile waters a centerpiece of the new initiative by endorsing achievement of "sustainable socio-economic development through the equitable utilization of, and benefits from, the common Nile Basin water resources" as their Shared Vision.

The potential profound change in the basin's unfavourable hydro-political configuration $^{52}$ adoption of the Shared Vision was believed to bring about was critical in motivating the reluctant upstream riparians into full membership and participation in the NBI process. The initiative brought about a "remarkable shift in the tone and substance of state-to-state relationships" ${ }^{\text {"53 }}$ ushering in a new era of rapprochement and cooperation which made possible the negotiation of an inclusive legal and institutional framework for over a decade. ${ }^{54}$

In spite of the relentless decade-long effort to make it a success, the NBI could not escape failure ${ }^{55}$ as the CFA which would have sealed the onset of a real change and progress was rejected by Egypt and Sudan, following which inter-riparian relationships rapidly deteriorated as rapprochement and optimism soon gave way to unprecedented rancor and sabre-rattling. This unfortunate turn of events compels an inquiry into whether there is any room left for cooperative development and shared utilization of the Nile waters. Given the obstinate stance of Egypt and Sudan with regards to the CFA, one would be justified to surmise that the initial endorsement of the Shared Vision by the two downstream riparian countries was a hegemonic ploy to preempt or delay unilateral actions by upstream riparian countries and buy time to pursue their own unilateral hydraulic projects. ${ }^{56}$

The situation has given upstream riparians, notably Ethiopia, the hard lesson that change in the inequitable status quo will not come from the negotiating

${ }^{51}$ Dereje, supra note 16, p. 427.

${ }^{52}$ Dereje, supra note 8, pp. 349-350.

${ }^{53}$ Brunnee \& Toope, supra note 24, p. 132.

${ }^{54}$ For a detailed discussion of the negotiation process and the challenges, see Dereje, supra note 16, pp. 427-431.

${ }^{55}$ A. Cascão (2009), "Changing Power Relations in the Nile River Basin: Unilateralism vs. Cooperation?” Water Alternatives 2(2), p. 263.

${ }^{56}$ Dereje Z. Mekonnen (2010), "From Tenuous Legal Arguments to Securitization and Benefit Sharing: Hegemonic Obstinacy - the Stumbling Block against Resolution of the Nile Waters Question”, Mizan Law Review 4(2), p. 234. 
table. For Ethiopia, the lesson has an element of a déjà vu reminiscent of the 1950s where a formal objection to its exclusion from the negotiation of the 1959 Agreement received no attention and thus made no impact. ${ }^{57}$ Egypt and Sudan ignored Ethiopia's plea and signed the 1959 Agreement which allocated the entire flow between them leaving nothing for the country contributing $86 \%$ of the flow. Ethiopia seems, this time around, to have taken its lessons from history that mere assertion of a right, however legitimate and well founded in law and equity, does not make a difference in reality unless the claimant demonstrates resolve to back it up with action.

Launched after almost all efforts for cooperative development have been frustrated, ${ }^{58}$ the GERD has proven to be a potent counter-hegemonic measure which jolted the malign hydro-hegemon ${ }^{59}$ hitherto unwilling to acknowledge the fundamental rights of upstream riparian countries. The GERD as such is, undoubtedly, a harbinger of change in a basin locked for decades in a hydrohegemonic stasis ${ }^{60}$ impervious to even moderate change. Whether the apparently inevitable change would materialize and ensure equitable utilization of the Nile waters by all basin states is far from certain as normative compliance producing mechanisms set in motion following the launching of the GERD pose a real challenge of institutionalizing the status quo to the advantage of the hydrohegemon.

\section{Twin Challenges Posed by the DoP}

The inequitable status quo in the Nile basin has been sustained mainly by the overwhelming power asymmetry undergirding Egyptian hegemony ${ }^{61}$ which was reinforced by the enduring weaknesses of upstream riparian countries which could not go beyond making claims to equitable and reasonable share of the

${ }^{57}$ M. Whiteman (1964), Digest of International Law (US Government Printing House), pp. 1011-1012.

${ }^{58}$ R. Tawfik (2016), "The Grand Ethiopian Renaissance Dam: a Benefit Sharing Project in the Eastern Nile?”, Water International 41(4), p. 577. Some Joint Multipurpose Projects abandoned following Egypt's rejection of the CFA and its withdrawal from the NBI include all efforts at cooperative development through JMPs under the auspices of the NBI frustrated by Egypt's rejection of the CFA and its withdrawal from the NBI: prefeasibility study of Karadobi hydropower project with installed capacity of $1600 \mathrm{MW}$; pre-feasibility studies of the Border Dam (now the GERD), a hydropower project with a storage capacity of $14.5 \mathrm{BCM}$ and an installed capacity of $800 \mathrm{MW}$, and Mandaya hydropower project with an installed capacity of 2400-2800 MW, all finalized in 2008.

${ }^{59}$ Woodhouse \& Zeitoun, supra note 44, p. 113.

${ }^{60}$ A. Cascão \& A. Nicol (2016), “GERD: New Norms of Cooperation in the Nile Basin?” Water International 41(4), p. 552.

${ }^{61}$ A. Cascão (2008), "Ethiopia-Challenges to Egyptian Hegemony in the Nile Basin”, 10 Water Policy Supplement 2, p. 15. 
waters doing little, in terms of launching hydraulic projects, to challenge the inequitable pattern of utilization. Continuation of the status quo has also been made possible by the successive cooperative initiatives which served, in large measure, as instruments of hegemonic control to stall potential developments upstream. $^{62}$

The launching of the GERD marks the first ever real challenge to the status quo which may induce a positive transformation in the basin by forcing the recalcitrant hydro-hegemon to accept the best scenario of cooperative development and shared utilization within the permanent legal and institutional framework brought into existence by the CFA. The likelihood of this scenario being pursued though is very slim as both Egypt and Sudan still believe in the possibility of perpetuating the status quo and have, to this end, adopted a twopronged strategy aimed at thwarting the transformative impact of the GERD and institutionalizing the status quo by eroding the fundamental principles of international water law.

\subsection{Institutionalization of the Status Quo}

The attempt to institutionalize the status quo by preempting the applicability of international water law as the framework within which the Nile waters question would find a lasting solution may be traced back to the inclusion of the principle of water security in the CFA. Although the principle was included with the hope and belief that it would help overcome the impasse in the negotiation process, it has turned out to be a Trojan horse of the inequitable status quo. ${ }^{63}$ The claim to exclusive right over the entire flow of the Nile pursued under the mantra of 'historical rights' which the principle of water security was hoped to dispel reappeared using the same principle as a convenient cloak.

Apparently a minor difference over a proposed amendment to a subprovision of the CFA (Article 14/b), the proper impact of the proposal in terms of redefining the substance of International Water Law in a manner conducive to the institutionalization of the status quo should not be overlooked. A closer reading of the proposal ${ }^{64}$ shows that it introduces two changes which would significantly redefine water security to mean an acknowledgement of the veritable ownership Egypt and Sudan claim over the entire flow of the Nile. The

${ }^{62}$ Dereje, supra note 7, pp. 81-87.

${ }^{63}$ Id., pp. 90-92.

${ }^{64}$ Annexed with the CFA to be resolved by the Nile River Basin Commission within six months of its establishment, Article 14(b) to which all countries except Egypt and Sudan agreed spells out the obligation "not to significantly affect the water security of any other Nile Basin state." Egypt proposed a different formulation to replace the agreed version with obligation "not to adversely affect the water security and current uses and rights of any other Nile Basin State.” 
first change replaces the word "significant" by "adverse" thereby lowering the threshold of harm below the international law standard. The second and far more sinister change extends the scope of the obligation to include "current uses and rights". Given the fact that Egypt and Sudan are currently using the entire annual flow, the proposal signifies a position antithetical to the fundamental principles of international water law demanding upstream riparian states to forego their right to equitable and reasonable utilization of the Nile waters.

The DoP signed on 25 March 2015 by Ethiopia, Egypt and Sudan ${ }^{65}$ represents another challenge providing a new legal basis for the institutionalization of the status quo with little concession for upstream riparian Ethiopia. Although Egypt was intent on blocking implementation of the GERD project by all means, ${ }^{66}$ realization of its inability to stop the GERD which rather came to be a fact on the ground is the primary consideration which forced a change in strategy. ${ }^{67}$ Egypt, thus, came back to the negotiation process and signed the DoP with the objective of institutionalizing the status quo by a normative limitation of upstream riparian rights to non-consumptive utilization - essentially, hydropower generation.

The first prong of the new strategy is evident in the substance of the second principle of the DoP which, in spite of its alluring caption, limits the purpose of the GERD to power generation. ${ }^{68}$ With regards to the GERD, therefore, the exclusive consumptive utilization of the Nile waters by Egypt and Sudan has been transformed from being a challenged fact on the ground into a legal reality Ethiopia is bound to honor and respect. The trajectory of the new strategy

${ }^{65}$ Agreement on Declaration of Principles between the Arab Republic of Egypt, the Federal Democratic Republic of Ethiopia and the Republic of the Sudan on the Grand Ethiopian Renaissance Dam Project, signed at Khartoum, Sudan; official text available at http://www.hornaffairs.com/en/2015/03/25/egypt-ethiopia-sudan-agreement-ondeclaration-of-principles-full-text (last visited 15 July 2017).

${ }^{66}$ Tawfik, supra note 58, pp. 580-581. Egypt's initial response to the GERD was vehement opposition alleging violation by Ethiopia of international law, especially the obligation not to cause significant harm and the principles of prior notification and consultation as well as obligations under the 1902 treaty and the 1993 agreement both of which, allegedly, prohibit construction of the GERD as it would cause appreciable harm to Egypt. When Morsi assumed the Presidency, the challenge took the old-fashioned tactics of "threatening to use force if Egypt's share of the Nile waters were affected, insisting that Egypt accepted no infringements on its water security."

${ }^{67}$ Ibid. Tawfik explains Egypt's acceptance of the GERD as an unavoidable fact on the ground as a result of the realization of "the limitations of employing the empty rhetoric of threatening to use force, and referring to legal means."

68 The Second Principle on the GERD, captioned Principle of Development, Regional Integration and Sustainability, reads: "The purpose of GERD is for power generation, to contribute to economic development, promotion of transboundary cooperation and regional integration through generation of sustainable and reliable clean energy supply." 
becomes even more evident when the questionable limitation of the purpose of the GERD -a national project fully financed by Ethiopia- to power generation is contrasted with huge hydraulic projects launched by Egypt and Sudan with no discussion on what their purposes should be. The Southern Valley (Toshka) project in Egypt and Merowe Dam in the Sudan are prime examples.

Launched in 1997 for the purpose of reclaiming some 3.4 million feddans of agricultural land using 5.5 billion cubic metre of Nile waters pumped out of Lake Nasser, the project is expected to provide home for about 7 million Egyptians to be moved to the Southern Valley. ${ }^{69}$ With its objection conveniently ignored, all Ethiopia could do then was to make its position clear, through a March 20, 1997 note verbale to Egypt, that "it will not allow its share to the Nile waters to be affected by a fait accompli such as the Toshka project, regarding which it was neither consulted nor alerted."70

The Merowe Dam (Merowe Multi-Purpose Project), "Sudan's largest and most significant water project" with annual electricity yield of $1250 \mathrm{MW}$ and the potential for irrigation of up to 20,000 ha of land ${ }^{71}$ was completed in 2008. No upstream riparian country was "consulted or alerted" and Egypt, in spite of its concern about the irrigation plans, accepted the Merowe as a fact merely contending that its use should not go beyond power generation. ${ }^{72}$

The DoP which has become the latest vehicle for institutionalization of the inequitable status quo has been portrayed as a success for upstream riparian countries allegedly signifying recognition by Egypt and Sudan of "the equality of all the Nile states" and acknowledgement by both of "the right of these states to utilize the waters of the Nile for the sustainable development of their people". ${ }^{73}$ No part of the DoP, however, warrants such a wildly optimistic reading and, contrary to this unwarranted optimism, the Egyptian Ministry of Foreign Affairs has made it abundantly clear that it "will not affect historical agreements and the water share allocated in these agreements." ${ }^{, 74}$ The

${ }^{69}$ S. Lonergan \& A. Wolf (2001), "Moving Water to Move People The Toshka Project in Egypt A Water Forum Contribution”, Water International 26(4), p. 590. The enormous cost of the project (considered as Mubarak's Pyramid) out of which only 20 to 25 percent is to be borne by the government is claimed to be the reason behind Egypt's involvement with the NBI which was used as a symbol of riparian cooperation to bring World Bank investment into Egypt (Id., 591, 593).

70 S. Salman (2010), "Downstream Riparians Can Also Harm Upstream Riparians: The Concept of Foreclosure of Future Uses”, Water International 35(4), p. 358.

${ }^{71}$ M. Saleh (2008), "Hydro-hegemony in the Nile Basin: a Sudanese Perspective", 10 Water Policy Supplement 2, p. 33.

72 S. Salman (2016), "The Grand Ethiopian Renaissance Dam: The Road to the Declaration of Principles and the Khartoum Document”, Water International 41(4), p. 514.

${ }^{73}$ Id., p. 522.

${ }^{74}$ Tawfik, supra note 58, p. 582. 
unwarranted optimism about the DoP has also been reinforced by an equally unwarranted perception of Sudan's political support for the GERD" as "a ground shaking decision which virtually ended its more than half a century Nile alliance with Egypt." 76

In view of the fact that Sudan has become increasingly dependent on irrigation agriculture as a result of the huge loss of oil revenue entailed by the secession of the South Sudan, ${ }^{77}$ its support for the GERD is predicated on a pragmatic consideration of the variegated benefits the Dam avails to it, ${ }^{78}$ the most important one being expansion of its irrigation potential ${ }^{79}$ using the regulated flow of the Blue Nile -a huge benefit of GERD it will enjoy with no cost. The DoP, thus, signifies a renewed convergence of strategic objectives rather than the waning of half a century of alliance between Egypt and Sudan.

\subsection{Erosion of the Fundamental Principles of International Water Law}

The relevance and irreplaceable role of International Water Law in bringing about a durable solution for the restive Nile basin cannot be disputed. The prospect for such a solution has, however, been significantly undermined by a series of factors including stagnation of the $\mathrm{NBI}{ }^{80}$ "riparian race to unilaterally capture as much of the resource as possible through a multitude of giant hydraulic projects" ${ }^{\prime 1}$ and rejection of the CFA which is indicative of a far more serious challenge -rejection of international water law as the appropriate framework within which the Nile waters question should be resolved. In light of this, cutting a deal with two recalcitrant riparian states who stand in opposition to the CFA showing no signs of moderation does not bode well for the CFA and

${ }^{75} I d$., p. 579. Sudan's political support for the GERD is predicated on the potential benefits of the project in terms of flow regulation which would significantly increase the irrigated agricultural and reduction in sedimentation which would improve the operation of its dams.

${ }^{76}$ Salman, supra note 72, p. 518.

${ }^{77}$ Tawfik, supra note 58, p. 585.

${ }^{78}$ D. Whittington, J. Waterbury \& M. Jeuland (2014), “The Grand Renaissance Dam and Prospects for Cooperation on the Eastern Nile", 16 Water Policy, p. 600.

79 A. Tesfaye (2014), "Conflict and Cooperation and the Evolution of the Nascent Nile Basin Regime”, Northeast African Studies 14(1), p.130. Sudan has planned expansion of its irrigated agriculture from 2 to 4.8 million ha requiring 25 billion cubic metre of additional water annually. See also A. Swain (2011), "Challenges for Water Sharing in the Nile Basin: Changing Geo-politics and Changing Climate", Hydrological Sciences Journal 56(4), p. 694, stating the fact that due to increased irrigation, potential demand for Nile waters in the Sudan is estimated to increase to 32 billion cubic metre by 2025.

${ }^{80}$ O. Yohannes \& K. Yohannes (2012), "Turmoil in the Nile River Basin: Back to the Future?” Journal of Asian and African Studies 48(2), p. 204.

${ }^{81}$ Ibid. 
undermines the common upstream position against the status quo painstakingly built over the years under the leadership of Ethiopia. ${ }^{82}$

Purportedly an agreement on declaration of principles on the GERD Project, the DoP goes way beyond the specific issues pertinent to the Project and ventures into a treacherous redefinition of the core principles of International Water Law unanimously adopted as core principles of the CFA as well. ${ }^{83}$ The redefinition of core principles in the DoP involves significant omissions signaling "erosion of the norm-building feature of international law ... by those seeking to maintain the status quo". ${ }^{84}$ Principles III and IV of the DoP which provide for the principle not to cause significant harm and the principle of equitable and reasonable utilization, respectively, signify such erosion which arguably constitutes the second prong of the new strategy to perpetuate the status quo.

As formulated in Principle III, the principle not to cause significant harm has undergone a substantive reformulation. The principle commits, in its first paragraph, the three countries "to take all appropriate measures to prevent the causing of significant harm in utilizing the Blue/Main Nile." The second paragraph which involves a significant omission with serious normative repercussions reads: "Where significant harm nevertheless is caused to one of the countries, the state whose use causes such harm shall, in the absence of agreement to such use, take all appropriate measures in consultations with the affected state to eliminate or mitigate such harm and, where appropriate, to discuss the question of compensation."

This reformulation involves a significant omission of the phrase "having due regard for the provisions of Articles 5 and 6" found in Article 7(2) of the UN Watercourses Convention which is copied verbatim in Article 5(2) of the CFA. ${ }^{85}$

${ }^{82}$ Cascão \& Nicol, supra note 60, p. 562. F. Lawson (2016), "Desecuritization, Domestic Struggles, and Egypt's Conflict with Ethiopia over the Nile River", Democracy and Security 12(1), p. 2, notes the fact that Egypt has given attention to maintaining good relations with White Nile riparian states of Uganda, Kenya and Tanzania in a bid to ensure monopoly and isolate Ethiopia thereby weakening the common challenge to the status quo.

${ }^{83}$ It is important to note that out of the fifteen general principles of the CFA which constitute the normative foundation for the use, conservation and development of the Nile water resources, only one - the principle of water security - was and still continues to be a point of disagreement between Egypt and Sudan and the upstream riparian states.

84 M. Zeitoun (2015), "The Relevance of International Water Law to Later-developing Upstream States”, Water International 40(7), p. 950.

${ }^{85}$ The reference in the CFA to Art 4 is exactly the same, in substance, to the reference to Art 5 and 6 made in Art 7(2) of the WCC as Article 4 of the CFA provides, in one provision, the principle of equitable and reasonable utilization together with relevant factors and 
The implication of this arguably deliberate omission is immense as it dispenses with a crucial reference to the principle of equitable and reasonable utilization and relevant factors and circumstances (Articles 5 and 6 of the UN Watercourses Convention and Article 4 of the CFA) which serve as important determinants of the type of prohibited harm falling within the ambit of the principle.

Reformulation of the principle in the DoP has effectively removed an essential element of the principle which provides the point of reference for resolution of disputes regarding the legitimacy of a given utilization which might be challenged as causing significant harm -thus blurring the distinction between factual harm and harm constituting legal injury. Consequently, any harm would inevitably be classified as significant and be prohibited on account of factual considerations -a conflation of factual harm with legal injury which would legitimize the untenable status quo by prohibiting any consumptive utilization upstream. ${ }^{86}$

The principle of equitable and reasonable utilization, redefined as Principle IV in the DoP, is the lynchpin of international water law unanimously accepted as one of the principles of the CFA. According to this principle, every riparian state is entitled, within its own territory, to a reasonable and equitable share of the waters. Hence, allocation where this has not taken place, and re-allocation in the case of the Nile basin where the entire flow has already been fully allocated between the two downstream riparian countries, is an unavoidable necessity which is an integral part and a necessary outcome of the principle. ${ }^{87}$

Allocation / re-allocation is sine qua non not only for a proper understanding of what harm means in the context of the "no-significant harm" principle, but also for the practical implementation of the principle of equitable and reasonable utilization through the incipient mechanism of benefit sharing. Contrary to the alleged advantage of benefit sharing to obviate the daunting task of water allocation, the negotiation of water rights and of benefits are not alternative

circumstances provided for under Art 5 and 6 of the UN Watercourses Convention, respectively.

${ }^{86}$ Tawfik, supra note 58, p. 583. Egypt's concern remains to be "the impact of the project on its historical share of the Nile water" which can only be maintained by proscription of consumptive use upstream. The signing of the DoP was fiercely opposed by some Egyptian policy circles for whom it "meant that Egypt would formally accept the GERD without legally committing Ethiopia to respect Egypt's historical share” Id., p. 585.

${ }^{87}$ McCaffrey, supra note 21, pp. 325, 345; P. Birnie \& A. Boyle (2002), International Law and the Environment ( $2^{\text {nd }}$ ed., Cambridge University Press), p. 303; A. Nollkaemper (1996), "The Contribution of the International Law Commission to International Water Law: Does it Reverse the Flight from Substance?” 27 Netherlands Yearbook of International Law, pp. 39, 44. 
strategies; rather, “an explicit or implicit recognition or negotiation of property rights is a necessary precondition for the realization of a benefit sharing scheme". 88

In spite of the centrality of re-allocation for a lasting resolution of the Nile waters question, the DoP has redefined the principle by carving out a section of the definition in Article 4 of the CFA which emphasizes the need for water sharing or allocation as an essential element of the principle. Compared to the definitions in Article 5 of the UN Watercourses Convention and Article 4 of the $\mathrm{CFA}^{89}$ the definition in principle IV of the $\mathrm{DoP}^{90}$ which commits the three countries to "utilize their shared water resources in an equitable and reasonable manner" without any reference to the CFA or the UN Watercourses Convention is all but a mere shadow of the principle. Considered in conjunction with Principle II which limits the purpose of the GERD to power generation and the exclusion of any reference to water sharing or re-allocation which is an integral part of the principle clearly stipulated in Article 4 of the CFA, the principle has been substantially reformulated in such a way that it would provide a convenient normative basis for the beleaguered status quo.

\section{Conclusion}

Equitable and reasonable utilization of transboundary watercourses is a lofty objective, the realization of which depends on the proper implementation of the twin core principles of international water law: equitable and reasonable utilization and the obligation not to cause significant harm. The first is a constitutive principle which determines the rights of riparian states while the second is an interpretive principle which circumscribes the same. ${ }^{91}$ Determination of what is equitable and reasonable in a given case is a responsibility of basin states which they should carry out through negotiation of

${ }^{88}$ I. Dombrowsky (2009), "Revisiting the Potential for Benefit Sharing in the Management of Trans-boundary Rivers”, 11 Water Policy, pp. 125, 137.

${ }^{89}$ Art. 4 of the CFA reads: "Nile Basin states shall in their respective territories utilize the water resources of the Nile River system and the Nile River Basin in an equitable and reasonable manner. In particular, those water resources shall be used and developed by Nile Basin States concerned, consistent with adequate protection of those water resources. Each basin state is entitled to an equitable and reasonable share in the beneficial uses of the water resources of the Nile River system and the Nile River Basin (emphasis added).”

${ }^{90}$ The corresponding definition of the principle in Principle III of the DoP reads: "The three countries shall utilize their shared water resources in their respective territories in an equitable and reasonable manner."

${ }^{91}$ Fuentes, supra note 32, pp. 130-135; McCaffrey, supra note 21, p. 371; Birnie \& Boyle, supra note 87, p. 308. 
specific watercourse agreements. ${ }^{92}$ Once the specific rights of riparian states are determined in an inclusive agreement, the obligation not to cause significant harm circumscribes the right by obliging riparian states to take all appropriate measures to prevent the causing of significant harm constituting a legal injury to other riparian states.

The status quo in the Nile basin negates these fundamental principles of international law as it allegedly vests Egypt and Sudan with exclusive right to the entire flow of the Nile. Their rejection of the CFA is evidence of their unwillingness to abide by the rules of international law. Being downstream riparian states, Egypt and Sudan can, however, do nothing to stop developments upstream and the absence of cooperation will harm them most. Besides, absence of an inclusive legal framework or rejection of the same by some riparian states as in the case of the CFA does not in any way prevent the exercise by riparian states of their sovereign right to equitable and reasonable utilization in their territories.

The launching of the GERD after the frustration of almost every opportunity for cooperative development and shared utilization is a significant counterhegemonic measure capable of transforming the basin's hydro-political configuration as evidenced by Egypt's ultimate willingness to negotiate with Ethiopia. The context in which this negotiation was carried out and the substance of the final agreement in the form of the DoP, however, pose serious challenges for the prospect of change. In view of the unmitigated opposition of Egypt and Sudan to the CFA and the complete disengagement of the former from the NBI process, there is sufficient reason to beware of the consequences of a counterproductive flight away from cooperation into unilateralism and the erosion of fundamental principles of international water law through a patchwork of individual agreements for every hydraulic project upstream.

The GERD is meant for a typical non-consumptive use -power generationwhich does not involve flow reduction. It should, however, be clearly emphasized that Ethiopia's undisputed sovereign right to equitable and reasonable utilization of the Nile to which it contributes $86 \%$ of the annual flow cannot be limited to the non-consumptive use of power generation. Reduction of the flow of the Nile as a result of consumptive utilization upstream should be acknowledged in every deal as an inevitability firmly anchored in international law.

92 This is evident from the language of Article 3 of the UN Watercourses Convention which, in paragraph three, provides that "[w]atercourse states may enter into one or more agreements ... which apply and adjust the provisions of the present Convention to the characteristics and uses of a particular international watercourse or part thereof.” 